\title{
FEMALE MANAGERS AND THEIR WAGES IN CENTRAL EUROPE
}

\author{
Štěpán Jurajda \\ Teodora Paligorova
}
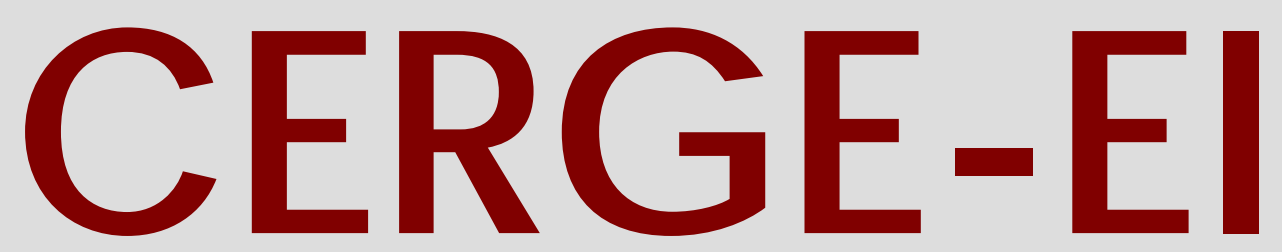

Charles University CenterforEconomic Research and Graduate Education Academy of Sciences of the Czech Republic Ec onomic Institute 


\title{
Working Paper Series 296 (ISSN 1211-3298)
}

\section{Female Managers and Their Wages in Central Europe}

\author{
Štěpán Jurajda \\ Teodora Paligorova
}

CERGE-EI

Prague, April 2006 
ISBN 80-7343-091-6 (Univerzita Karlova. Centrum pro ekonomický výzkum a doktorské studium) ISBN 80-7344-080-6 (Akademie věd České republiky. Národohospodářský ústav) 


\title{
Female Managers and Their Wages in Central Europe
}

\author{
Štěpán Jurajda and Teodora Paligorova*
}

CERGE-EI**

April 2006

\begin{abstract}
This paper examines the gender gaps in employment and wages among top- and lowerlevel managerial employees in a recent sample of Czech firms. Unlike the existing analyses of managerial gender pay gaps, we acknowledge the adverse consequences of the low and uneven representation of women for the Oaxaca-Blinder decomposition and offer an alternative set of results based on a matching procedure. Only $7 \%$ of top-level Czech managers are women and their wages are about 20 percent lower even when compared only to their comparable male colleagues.
\end{abstract}

\begin{abstract}
Tento článek zkoumá zastoupení žen a platové rozdíly mezi muži a ženami na středních a vrcholových manažerských pozicích pro výběrový soubor firem v ČR z let 2000 až 2004. $\mathrm{Na}$ rozdíl od existujících analýz (rozkladů) platových rozdílů podle pohlaví mezi manažery, naše empirická metodologie není náchylná zkreslení způsobenému malou mírou zastoupení žen v souboru; místo obvyklých rozkladů metodou Oaxaca-Blinder totiž používáme rozklady založené na tzv. párování (matching). Pouze $7 \%$ vrcholových manažerů v místních firmách jsou ženy. Pokud srovnáme hodinové výdělky manažerů se srovnatelným vzděláním zaměstnaných ve srovnatelných firmách, pak jsou u žen asi o 20 procent nižší než u mužů.
\end{abstract}

JEL Classification: J31, J71, P31

Acknowledgements The authors are grateful for data assistance provided by Vladimír Smolka of Trexima, Ltd. This research is part of the EU Equal project "Fifty - fifty: Equal Opportunities for Women and Men" and is co-financed by the European Social Fund of the EU and the state budget of the Czech Republic.

*E-mail: stepan.jurajda@cerge-ei.cz, teodora.paligorova@cerge-ei.cz

**CERGE-EI is a joint workplace of the Center for Economic Research and Graduate Education, Charles University, and the Economics Institute of the Academy of Sciences of the Czech Republic.

Address: CERGE-EI, P.O. Box 882, Politických vězňů 7, Prague 1, 111 21, Czech Republic.

Jurajda is also affiliated with CEPR and IZA. 


\section{Introduction}

There is growing evidence that women face a 'glass ceiling' - a barrier to career prospects, which precludes them from achieving high-paying positions and having equal wages with men especially in the upper part of the wage distribution (e.g., Albrecht et al., 2003). A particularly visible and influential type of high-paying position is that of the manager. The representation of women among top-level managers and their relative wage position are therefore of high general public interest. The increasing share of female executives and the narrowing managerial gender pay gap in the U.S. may represent a cracking of the discriminatory 'glass ceiling' (Bertrand and Hallock, 2001; Bell, 2005). Studying managerial compensation is also important because it may help us credibly isolate the discriminatory component of gender pay gaps: gender wage gaps among homogenous groups of highly motivated and educated workers, such as top-level managers, may be little affected by gender differences in unobserved labor quality.

The analysis of managerial gender gaps is particularly significant in the post-communist economies of Central Europe, where firm personnel strategies and corporate governance are converging towards Western standards (Denis and McConnel, 2003), but where little is known about the relative position of female executives. While there are now several studies of the gender pay gap in these economies (see Section 2), none focus on managers. This paper provides such an analysis for a large sample of Czech managerial employees from 2000-2004, including a wage gap decomposition controlling for firm and individual characteristics. Unlike most of the existing work on managers, our analysis covers not only top executives, but also mid-level managers and employees, thereby allowing us to link the relative position of women across firm hierarchy levels.

Our managerial gender wage gap decompositions appear to be the first available outside of the most developed economies. Furthermore, unlike the existing literature on gender 
pay differences among executives, we recognize the adverse consequences of the low and uneven representation of female managers for the standard parametric Oaxaca-Blinder decomposition technique. The goal of any decomposition is to compare the wages of males and females with similar individual characteristics working in similar companies. Given the low representation of women among top managers, however, there will be a significant share of male managers for whom no 'comparable' women will be observed. Such a lack of 'common support' is strengthened by gender-related sorting into specific types of firms or managerial occupations. Linear regression models used in the Oaxaca-Blinder techniques will therefore project the conditional wage distribution of women onto regions of the male wage distribution in which females are virtually nonexistent.

Recent work by Nopo (2004) and Black et al. (2004) studying gender wage gaps (but not focusing on managers) suggests that such parametric assumptions lead to overestimation of the 'unexplained' component of the gap, i.e. the part of the gap attributable to differences in rewards to individual characteristics and often interpreted as an upper bound on the extent of gender discrimination. Following on this recent work, we therefore employ a nonparametric matching approach, which accounts for the gender differences in the 'support' of firm characteristics and does not impose a linear functional form of conditional wage expectations. This is not important only as a robustness check on standard estimation techniques. Matching also aids in the interpretation of the data because it separates the part of the observed pay gap that 'occurs' among comparable male and female managers from the part that corresponds to women not being represented at all in the managerial workforce of certain firm types.

We find Czech women to be well represented among low-level managers but severely under-represented at the top of firms' hierarchies, where the overall gender pay gap is also the largest. In accord with the existing literature, our nonparametric estimates imply a 
smaller 'unexplained' part of the overall pay gap than regression-based techniques. Even after we compare male and female managers with similar education and age and working in similar firms, female wages are about 20 percent lower. We also find a strong within-firm link between the relative position of women at different hierarchy levels.

The remainder of this paper is organized as follows: Section 2 explores the related literature, Section 3 describes the data, and Section 4 presents basic gender-related statistics. Section 5 then covers the OLS- and matching-based decomposition techniques while Section 6 discusses the estimated wage-gap decompositions. We also relate the relative position of women in a firm's management to that in the firm's employee workforce in Section 7 and contrast our findings with those from the U.S. literature in Section 8. Concluding remarks are offered in Section 9.

\section{Background}

Our analysis builds on several strands of research. First, we extend the small literature on the gender wage gap among managers. Second, we complement the extensive set of gender wage gap analyses from post-communist economies. Third, we follow on the first gender-wage-gap applications of the recently developed matching evaluation techniques. In this section, we briefly discuss each of the related areas of research.

\subsection{Female Managers and their Wages}

There are now two detailed studies of the gender gap in top corporate jobs in the U.S., both relying primarily on Standard and Poor's ExecuComp data, which contain information on the five highest-paid executives in large publicly traded U.S. firms. Bertrand and Hallock (2001) study the data from 1992 to 1997 and find that women represent about $2.5 \%$ of the sample and earn about $45 \%$ less than men. Bell (2005) covers the 1992-2003 
period and reports a much smaller average gap in gross compensation of $25 \%$, suggesting dramatic reductions in the gap after 1997. Both studies show that women gradually increase their participation in top executive ranks (to over $6 \%$ after 2001) as well as their relative compensation. They both also suggest that about 50 to $75 \%$ of the raw wage gap can be 'explained' by women being less likely to manage large companies and to be CEO, Chair or company President. ${ }^{1}$

Both of these studies argue that male and female top-ranking managers are similarly educated and motivated, which makes it unlikely that their observed gender wage gap can be explained by unmeasured differences in human capital or motivation. Hence, if there is a significant unexplained component of the gender wage gap, it is likely to be due to employer gender discrimination. ${ }^{2}$ However, this exclusive interpretation of the unexplained gap has been recently challenged by research focusing on female-specific performance in managerial tasks. Gneezy et al. (2003) suggest that women may be less effective than men in competitive environments, even if they can perform similarly well in non-competitive environments. In a related line of work, Babcock and Laschever (2003) report that women may not negotiate as toughly as men on salary issues.

The ExecuComp data used in the U.S. research report information on different com-

\footnotetext{
${ }^{1}$ There is so far little connection between this gender-wage-gap empirical research and the literature on executive compensation focusing on the incentive effects of the structure of managerial rewards (see, e.g., Murphy, 1999). While managerial pay differentials have been explained by diverse organizational performances, firm size and industry, the impact of gender on managerial pay has received much less attention in this literature.

${ }^{2}$ A similar argument has been put forward by other studies focusing on the highly paid. For example, Wood et al. (1993) explore the gender wage gap among U.S. lawyers. Even though their analysis controls for rich human-capital and job-related characteristics, about one-third of the earnings gap remains unexplained.
} 
ponents of executive pay including salary, annual bonus, incentive bonus, and the value of stock options. Bell (2005) finds that the 'unexplained' gender wage gap is not sensitive to different types of compensation measures. She also reports a positive relationship between the presence of a female CEO and the representation and relative wages of other female top-paid managers.

Outside of the U.S., there is so far apparently only one study of the gender pay differences among executives. Gregg and Machin (1993) study British senior managers and find that women are less likely to be promoted and are paid $30 \%$ less. Furthermore, two thirds of this raw pay gap is not explained by their observable characteristics.

Little is therefore known about the relative position of female managers in most other countries. Standard international data provide no detailed information on the structure of the male-female pay gap among managers. The only widely available related statistic is the women's share as legislators, senior officials and managers, i.e. their share in the 1st major group of the ISCO-88 occupational classification. This statistic can be computed from household surveys, such as the widely available Labour Force Surveys, and is also featured in the International Labour Organization's Yearbooks (see, e.g., ILO, 2004). However, it is likely that this share is dominated by the fraction of women among the large group of senior officials and may therefore over-estimate female representation among top managers. $^{3}$

To provide an aggregate cross-country comparison of the relative gender employment among managers of large firms, we use the Luxembourg Income Study (LIS), which harmonizes labor-market micro data from several countries. ${ }^{4}$ This data allows us to focus

\footnotetext{
${ }^{3}$ For example in the 2003 and 2004 Czech Labor Force Surveys, about $90 \%$ of the ISCO 1st major group was composed of senior officials, which includes municipality and public-administration officials.

${ }^{4}$ The LIS collects information at the individual and household level from labor force surveys. The data is available at www.lisproject.org .
} 
on managers of large firms (occupation group 12 of the ISCO-88 classification) and to measure both the fraction of women in this group and the corresponding gender wage gap. Table 1 shows that the share of females in this occupational group varies widely from $17 \%$ in Belgium to $43 \%$ in the USA. The hourly pay gap, defined as the ratio of female to male average wages minus one is high in Russia, Spain, and the U.S., and the smallest for Ireland and Slovenia. In the Czech Republic females constitute only about $23 \%$ of the group of legislators, senior officials and managers. The corresponding gender pay gap, at $24 \%$, is then close to the average gap taken across our small sample of countries. Based on this aggregate comparison, it therefore appears that the Czech Republic is a quite typical country in terms of the relative position of women in this most prestigious group of workers.

\subsection{Wages in Post-Communist Countries}

Much research now studies the size and structure of the gender wage gap in post-communist economies. A typical finding in this literature is that only a small part of the pay gap can be attributed to gender differences in productive characteristics. Several studies also point out the adverse effect of increasing wage inequality for the relative wage position of women and the important role of decreasing low-wage female labor force participation for explaining the observed reductions in the overall gap. ${ }^{5}$

On the other hand, there is relatively little research on gender segregation (and the changes thereof) across occupations in these countries. Ogloblin's (1999) analysis implies a major role for occupational segregation in accounting for the observed gender wage gap in Russia in the early 1990s. Similarly, Jurajda (2005), who examines Czech data from 1998

\footnotetext{
${ }^{5}$ For recent gender wage gap decompositions from Central Europe see Jolliffe and Campos (2005) or Jurajda (2005).
} 
and 2002, suggests that a large part of the stable gender wage gap is due to segregation of women into low-paying occupations and firms. Still, he finds the unexplained component of the gap in the Czech Republic to be much larger, suggesting an extensive potential role for within-job wage discrimination. ${ }^{6}$

The history of occupational gender segregation (Ogloblin, 1999) as well as the recent evidence on the presence of important segregation effects and on potential within-job wage discrimination all motivate the study of gender gaps in the highly visible role-model managerial occupation group. Yet, the literature on managerial pay in post-communist economies is miniscule as it apparently consists of two papers, both focusing on the relationship between managerial compensation and firm performance. While Jones and Kato (1995) examine the pay of Bulgarian managers immediately after the collapse of communism, Eriksson (2005) studies a recent sample of Czech and Slovak managers. He finds that private firms offer higher pay than state-owned companies and confirms a positive link between managerial compensation and company performance. There are $7 \%$ of females in his 2000 sample of 600 Czech CEOs responding to an earnings survey; he offers no further detail as to the gender structure of managerial employment.

\subsection{Matching-Based Gender-Wage-Gap Decompositions}

The vast majority of the existing gender wage gap studies and all of the managerial wage gap research employs the Oaxaca-Blinder decomposition to separate the part of the observed raw gap attributable to differences in average worker characteristics and the part due to differences in the rewards of these characteristics (i.e. the 'unexplained' part). This approach, however, relies on restrictive parametric assumptions about the functional form

\footnotetext{
${ }^{6}$ Differences in observable worker characteristics explain little of the overall wage gap in his analysis. See also Munich et al. (2005) who find that during the transition from central planning to market, Czech returns to education have risen at a similar pace for men and women.
} 
of the wage conditional expectation function, which could lead to misleading results, especially when there are important differences in the supports of the empirical distributions of male and female individual characteristics.

For example, consider the likely case of women not being represented in certain types of firms or occupations. In this situation, the regression-based traditional framework will attempt to compare male and female wages conditional on a given set of characteristics by projecting the conditional wage distribution of women onto regions of the male wage distribution in which females may be virtually nonexistent. Recent work reviewed below suggests that employing the regression-based techniques and thus ignoring this comparability issue, often referred to as the 'common support' problem, can lead to misleading results. $^{7}$

The alternative non-parametric decomposition technique, advocated recently in the program evaluation literature (see, e.g., Heckman et al., 1998), relies on comparing only wages of 'matched' men and women - those with a very similar set of observed characteristics. The matching approach then remains silent about the extent of wage differences between men and women in those types of firms or occupations from which women are generally absent.

There are now the first few applications available of the matching approach to gender wage gap decompositions. Nopo (2004) matches men and women with an exactly identical combination of observed characteristics. In his analysis of Peruvian workers, he finds that 23 and $30 \%$ of males and females, respectively, fall outside the 'common support' - that is, have no comparable workers of the opposite gender - and that about one quarter of the raw gender wage gap is due to this difference in support. Black et al. (2004) also

\footnotetext{
${ }^{7}$ In a related line of work, Heckman et al. (2003) reject the functional form of the Mincerian wage regressions.
} 
use this so-called exact matching approach to estimate the 'unexplained' gender wage gap among highly educated white, black, Hispanic, and Asian workers in the U.S. ${ }^{8}$ Both studies compare results based on matching with those of the traditional parametric approach and suggest that the explained portion of the overall raw gap is typically significantly higher when matching is used.

We take away the lesson that analyses of gender wage gaps should compare results based on linear regressions with those based on the intuitively more appealing matching decompositions, especially in situations where either men or women are not represented across the whole range of explanatory characteristics.

\section{Data}

We use data from a national employer survey, the Information System on Average Earnings (ISAE), from the first quarters of 2000 to 2004 . The enterprise survey is conducted by a private agency on behalf of the Czech Ministry of Labor and Social Affairs and firm response is mandatory. ${ }^{9}$ It contains hourly wages, gender, education, age, and a detailed occupational classification for each worker employed in the sampled firms, which also report their total employment, ownership and industry (using the NACE classification). ${ }^{10}$ The wage records are drawn directly from firms' personnel databases and the definition of hourly wage is detailed and fully consistent across firms; it includes total quarterly

\footnotetext{
${ }^{8}$ The exact matching approach may be unnecessarily strict as it may discard male and female workers with highly similar, but non-identical characteristics. We therefore apply and compare several alternative matching strategies in Section 5.2.

${ }^{9}$ The data do not cover the public sector (education, health and public administration), where wage determination follows budgetary rules and is based on wage grids.

${ }^{10}$ We cannot construct an individual panel due to lack of personal identifiers.
} 
cash compensation and bonuses divided by total hours worked for that quarter. ${ }^{11}$ Having available a measure of hourly wage rates is ideal for the purpose of estimating differences in the pay of men and women because of the potential gender differences in hours worked. On the other hand, it is possible that Czech executive pay packages also contain other forms of compensation such as stock options, which are therefore ignored in our analysis. There is no systematic evidence on the extent of the use of stock options in post-communist countries.

A detailed occupational classification (ISCO-88) is used to identify managerial employees at three levels: (i) chief executives and directors (ISCO code 121), (ii) production managers and supervisors (ISCO 122), and (iii) specialist managers and supervisors in finance, administration, personnel, sales and marketing, distribution, or computing (ISCO 123). In this study, the first group is referred to as top-level managers. Many firms report more than one top manager. Next, we combine production and specialist managers under the heading of lower-level managers. In some cases, we will bring into the analysis a third, benchmark group of all regular employees. ${ }^{12}$

The original stratified random sample drawn from the country for-profit firm register consists of 2000 firms on average per year over the 2000-2004 period, and covers all industries, ownership groups and firm sizes (above 10 employees) with a natural over-

\footnotetext{
${ }^{11}$ Annual bonuses are applied proportionately to each quarter in calculating the quarterly average wage rate.

${ }^{12}$ In a subset of our analysis in Section 8, we also use another alternative classification of managers, which distinguishes three managerial levels: (i) chief executives and directors (ii) directors in finance, administration, personnel, sales and marketing, distribution or computing, and (iii) all other managers and supervisors. This alternative classification employs the fact that the Czech version of ISCO- 88 introduces specific 5th digit codes, which allow us to identify group (ii).
} 
representation of large firms. ${ }^{13}$ In our analysis we focus only on large firms - those with more than 250 workers - as the position and role of managers are defined more precisely in large organizational structures. The ownership grouping available in the data distinguishes foreign-majority, domestic-private-majority, state-majority, and no-majority (mixed) firms. We also omit large cooperatives (about 200 firms on average per year), because of their different legal and corporate governance framework (Bonin et al., 1993). The number of sampled large firms is evenly distributed across years, with the maximum of 733 in 2001.

As a result, we start with a sample of 3,297 firm-year observations. Unfortunately, wage records for top-level managerial employees are missing in almost a third of this pool of observations. Table 2 presents the size of the sample and the extent of non-reported managerial compensation across years. Fortunately, many of the firms that do not report managerial wages in one year do so in another. In the whole five-year period, a total of 1,011 different firms are covered, out of which 218 do not report top-level managerial wage records in at least one year. The incidence of not reporting managerial wages is unrelated to observed firm characteristics. ${ }^{14}$ Still, a potentially non-random response rate with respect to the relative position of female managers is a potential weakness of our analysis. $^{15}$

Given the stable wage structure in the Czech Republic during our study period (Jura-

\footnotetext{
${ }^{13}$ The 2001 ISAE sample covers 38 (58) [64] percent of firms employing 250-500 (500-1000) [over 1000] employees.

${ }^{14}$ We estimated a logit model for the incidence of missing top-manager wages controlling for firm ownership type, industry and the number of employees. None of the estimated set of parameters was statistically significant. These results are available upon request.

${ }^{15}$ We evaluate this potential problem indirectly in Section 7, where we establish the within-firm correlation in relative female position across firm hierarchy levels.
} 
jda, 2005) and the goal of focusing on the small group of female top-level managers, our strategy is to combine the firm-year observations with available managerial wage records to maximize the size of the cross-section of firms, at the cost of combining data from different years. Specifically, we apply the two alternative sample selection procedures presented in Table 2. The first procedure, labeled as Sample I, starts with the year with the maximum number of reported firms, 2001, and then asks whether some of the 259 firms that do not report top-level managerial wages in 2001 do so in another year. ${ }^{16}$ This search detects 118 such firms, which allows us to work with a pseudo-2001 cross-section of 592 firms.

The second procedure, Sample II, selects one firm-year observation from the five year sample period based on several criteria. ${ }^{17}$ In comparison to Sample I, Sample II covers firms that did not appear in the 2001 data and as a result consists of 783 different firms reporting wages of almost 1,700 top-level managerial employees. It is reassuring that the fraction of women in this group is the same in both samples. In the parametric subset of our empirical analysis below, we compare results based on both samples, but we conduct the more data-hungry estimation on the larger sample. That is, we use Sample II for estimating simple gender comparisons by group and to apply the matching-based techniques. ${ }^{18}$

Overall, the data we use have several unique strengths as well as weaknesses. Among the strengths, it is a large data source covering the wage records of 1,692 top-level managers and over 36,000 lower-level managers. The data therefore allow us to study and relate

\footnotetext{
${ }^{16}$ In case a given firm reports managerial wages in more than one year, the year closer to 2001 is selected.

${ }^{17}$ We look for the year with the maximum number of reported top- and lower-level managers, which, however, does not vary much within firms, conditional on reporting. In case a given firm reports a similar number of managers in more than one year, the year closer to 2002 or 2003 is preferred.

${ }^{18}$ In all estimated regressions presented below, we include a set of year dummies.
} 
gender gaps at two managerial levels. ${ }^{19}$ The wage measure is free of reporting bias possibly present in survey data on managerial pay in less developed economies such as those used by Eriksson (2005). For the weaknesses, the data do not identify CEOs, ${ }^{20}$ there is a substantial fraction of firms not reporting managerial wages, and only wage data (including bonuses) but no other forms of compensation are reported. The last weakness may be of relatively small concern. First, salaries will likely constitute the bulk of compensation for lower level managers. Second, Bell (2005) finds that the unexplained portion of the gender pay gaps among top-level U.S. executives are similar when estimated off all-compensation or salary-only data.

\section{Gender Gaps in Wages and Employment}

A unique feature of our managerial wage data is that they allow us to compare the wage and employment patterns among two layers of managers as well as those prevailing among basic employees. Such comparisons are natural to the extent that lower-level managers are recruited from employees within industries or demographic groups and to the extent that top managers are promoted from lower-level ranks within firms. From an alternative perspective, these comparisons are interesting if the presence of a female top-level manager has a positive influence on the relative standing of lower-level female employees. ${ }^{21}$ While we are not able to distinguish between these two perspectives, we believe that the benchmark all-employee-based comparisons offered below aid in the interpretation of the descriptive

\footnotetext{
${ }^{19}$ We also observe non-managerial employees. There are 752,181 such wage records corresponding to Sample II.

${ }^{20}$ We note, however, that the fraction of women among all top-level managers in our data (7\%) is identical to the fraction of Czech female CEOs reported by Eriksson (2005).

${ }^{21}$ See Bell (2005) for several hypotheses on why this might be the case and an extensive list of related references.
} 
statistics for managers. ${ }^{22}$

Top-level managers in our data make on average 2.69 times more per hour than lowerlevel managers who, in turn, enjoy wage rates 2.46 times higher compared to those of basic employees. How well are women represented among these high-paid groups of workers? If the gender of managers were assigned randomly in a fashion reflecting the overall employment patterns, the share of female managers would be around $46 \%$, which is the fraction of females in the whole sample before dropping the non-response firms and the small firms. In contrast, our data show that only $7 \%$ of top managers are females, while women constitute $32 \%$ of all lower-level managers. ${ }^{23}$ Female top-level (lower-level) managers make on average $41 \%(38 \%)$ less per hour than their male colleagues, while the employee-based gender wage gap is $22 \% .^{24}$

Demographic patterns of gender-specific employment and wages are presented in Table 3 separately for the three hierarchy levels of top managers, lower-level managers and all remaining employees. Specifically, the table shows the fraction of females and the gender wage gap in each group (i.e. one minus the ratio of female to male average wages) as well as the relative pay position of a given group within a hierarchy level. ${ }^{25}$ Women are relatively

\footnotetext{
${ }^{22}$ We return to the relationship between relative female positions across hierarchy levels in Section 7.

${ }^{23}$ Our Czech data have a sister data set in Slovakia (collected by the same agency). However, the Slovak data are much smaller compared to the Czech sample as they cover only 227 non-cooperative firms employing over 250 workers as of 2002 . Of these firms, all report lower-level managers, but only $54 \%$ report top managerial wages. We therefore hesitate to use this data for detailed analysis. Nevertheless, the representation of women is similar to that found in the larger Czech sample as $7 \%$ of reported Slovak top managers are female, while $40 \%$ of lower managers are women.

${ }^{24}$ The median gender wage differential for top-level and lower-level managers is $41 \%$ and $37 \%$, respectively.

${ }^{25}$ In the Table, we report the statistical significance for tests asking whether the within-hierarchy groupspecific statistic is significantly different from that calculated using all data in a given hierarchy level. This
} 
highly represented among younger and especially among less educated top managers - and these groups of managers are also the least highly paid. Among lower-level managers, the wage gap is small in the group of highly educated, where there are also relatively little women. The representation of women and the gender wage gap are more equalized across major demographic groups in the large sample of basic employees.

Firm-level patterns of employment and wages are presented in Table 4, which focuses on firms' ownership type, size, and industrial sector. The results for top managers suggest that state-owned firms have the lowest gender pay gap and also feature more women at the top of the firm hierarchy compared to other ownership categories. Dividing firms into four quartiles by size (total employment) implies that females are more likely to be at the top of the few very large firms. Finally, the 'femaleness' of the top brass is highest in the relatively low-paying retail and transport/communication industries, where $38 \%$ of all female top managers work. ${ }^{26}$ The gender wage gap for top managers fluctuates across all industry branches, but is particularly high in the retail industry. ${ }^{27}$

Shifting attention to lower-level managers, Table 4 suggests that female representation in the managerial workforce is highest in state-owned and very large firms, similar to the case with top-level managers. The gender wage gap is now somewhat more equalized across firm types in comparison to the relevant top-level-managerial statistic. Looking at industry patterns of lower management's 'femaleness' we again find the retail and transport industries having high shares of women. More than half of all female lower managers are concentrated in transport/communication and manufacturing. However, the sector with

\footnotetext{
should help signal the amount of information available within each detailed data cell.

${ }^{26}$ We also note that banking and insurance feature a high share of female employees and lower-level managers, but a low share of female top managers.

${ }^{27}$ The construction and service industries are notable in that they exhibit very high shares of women among basic employees, but very low shares of female top-level managers and high gender wage gaps.
} 
the highest number of females - transport - pays some of the lowest wages and exhibits the second highest wage gap after banking and insurance.

Of course, these simple descriptive findings are hard to interpret as the cross-industry differences could be driven by a different demographic or firm-size composition of the sampled firms. Nevertheless, the evidence does suggest that female managers tend to be under-represented in the highest paid jobs and there appears to be a clear divide in the share of women between top- and lower-level managerial positions. The rest of this study asks to what extent the observed mean gender wage gaps among managers can be explained by the gender employment patterns and differences in demographic characteristics highlighted above.

\section{Decomposition Techniques}

\subsection{Regression-Based Decompositions}

The traditional Oaxaca-Blinder mean wage gap decomposition technique, which isolates the part of the overall gap related to observable differences between men and women, is based on estimating gender-specific linear log-wage regressions controlling for observed characteristics. We approximate the counterfactual non-discriminatory wage structure (Oaxaca and Ransom, 1994) with the 'male' regression coefficients based on running a regression on the sample of male managers. This choice makes our parametric decompositions comparable to the matching decompositions presented below. The approach we choose is to isolate the effect of belonging to the female demographic group by asking how much women would be paid if they were treated like men; this corresponds to estimating the effect of 'treatment on treated' in the terminology of the program evaluation 
literature. $^{28}$

We therefore decompose the gap between the male and female mean of the natural logarithm of hourly wages as follows:

$$
\text { Gap }=\overline{\ln w_{1}}-\overline{\ln w_{0}}=\left(\overline{X_{1}}-\overline{X_{0}}\right)^{\prime} \beta_{0}+\text { Unexplained Gap, }
$$

where $\overline{X_{1}}$ and $\overline{X_{0}}$ denote the respective vectors of female and male mean values of explanatory variables and $\beta_{0}$ stands for the estimated set of male slope coefficients. In order to reflect the likely presence of inter-dependence of unobservables within firms, we cluster residuals at the firm level in all reported specifications.

The estimated wage equations condition on individual characteristics (age groups and education degrees) and also control for firm characteristics (type of ownership, firm size and two-digit industry category). ${ }^{29}$ Introducing firm controls affects the interpretation of the unexplained gap because they absorb the potential barriers to the entry of women into managerial positions in certain firm types. ${ }^{30}$ Controlling for firm characteristics, however, helps us compare the wages of comparable female and male managers and therefore approximate more closely potential violations of the equal pay for equal work principle. This

\footnotetext{
${ }^{28}$ Oaxaca and Ransom (1994) suggest using the pooled-sample coefficients based on both men and women. Note, however, that given the low representation of women among top managers, this strategy is very close to using the male coefficients to approximate the non-discriminatory wage structure. Our results are almost identical when we weight the female and male coefficients with the gender-specific sample frequencies and use these pooled coefficients instead of the male slope parameters.

${ }^{29}$ Wage-age dependence is specified using a flexible step function with five-year intervals; education controls consist of four dummies for primary, apprenticeship, secondary and university degrees; ownership dummies correspond to majority foreign, private, state and mixed ownership; firm size is controlled for using a step function corresponding to deciles of the size distribution; finally, twelve industry dummies are also included.

${ }^{30}$ See Blau and Ferber (1987) for a similar discussion related to the inclusion of occupational controls.
} 
is also the goal of the matching approach presented below, which will allow us to decompose the overall gap into the part due to wage differences among comparable managers (explained and unexplained) and the part related to a lack of presence of female managers in certain firm types.

\subsection{Matching-Based Decompositions}

Non-parametric matching, which contrasts wages of ('matched') male and female workers with similar observable characteristics, is an intuitive alternative to regression-based methods. We again start with the total wage gap, defined as the difference between female and male conditional expected wages

$$
G a p=E\left(\ln w_{1} \mid D=1\right)-E\left(\ln w_{0} \mid D=0\right),
$$

where $\ln w$ is the natural logarithm of wages. We consider the 'treatment' effect of being a female $(D=1)$ as opposed to belonging to the 'control' demographic group of men $(D=0)$. The matching approach aims to estimate the missing counterfactual - what would a woman's wage be if she were a man. The answer is given by the wage of men with the same set of observable characteristics.

First, we sort both males and females into data cells, indexed by $k$, based on their age, education, industry, firm size and ownership. This allows us to write the overall average wage of females as $E\left(\ln w_{1} \mid D=1\right)=\sum_{k=1}^{n} p_{k} E\left(\ln w_{1} \mid D=1, k\right)$, where $E(\ln w \mid D=1, k)$ is the expected wage for females in the $k^{t h}$ cell and $p_{k}$ is the proportion of females in that data cell. Similarly, for men, we use $q_{k}$ to denote the proportion of males in the $k^{\text {th }}$ cell. Thus the gap can be expressed as

$$
G a p=\sum_{k=1}^{n} p_{k} E\left(\ln w_{1} \mid D=1, k\right)-\sum_{k=1}^{n} q_{k} E\left(\ln w_{0} \mid D=0, k\right)
$$


and by adding and subtracting $\sum_{k=1}^{n} p_{k} E\left(\ln w_{0} \mid D=0, k\right)$ we obtain

$$
G a p=\sum_{k=1}^{n} p_{k}\left[E\left(\ln w_{1} \mid D=1, k\right)-E\left(\ln w_{0} \mid D=0, k\right)\right]+\sum_{k=1}^{n}\left(p_{k}-q_{k}\right) E\left(\ln w_{0} \mid D=0, k\right) .
$$

This is of course reminiscent of the Oaxaca-Blinder decomposition. The first term in the equation describes how much less women would earn if they shared equal observable characteristics with men. The group-specific gender wage gap is averaged across groups with respect to the distribution of the "treated" $\left(p_{k}\right)$, resulting in an estimate of the 'average treatment on the treated' (ATT) in the terminology of the program evaluation literature or the 'unexplained gap' in the jargon of the regression-based decompositions.

Equation 2 makes clear that a basic requirement for the implementation of the matching approach is a sufficiently large overlap between the distribution of the observable characteristics of the "treated" and "untreated" individuals. This is known as the common support condition. In our application, it asks that for every female manager a sufficient number of 'similar' males be available. By the same token it stipulates that we only use 'similar' males for comparison with every female manager in our data and drop from the calculation of the ATT those males who work in firm types where no women are employed. The common support condition is ignored in the parametric decomposition techniques, which use functional form assumptions to project the conditional wage distribution of women onto regions of the male wage distribution in which females are virtually nonexistent.

Matching thus eliminates two of the three selection-bias sources highlighted by Heckman et al. (1998): the bias resulting from having different ranges of $X$ (characteristics) for the treated and control (comparing non-comparable individuals) and the bias resulting from having different distributions of $X$ across their common support (weighting comparable individuals incomparably). The absence of the third source of the bias, namely differences in unobservables across groups, is a condition for the correct identification of 
the ATT; it also the condition underlying the interpretation of the 'unexplained gap' as corresponding to discrimination. We believe that it is reasonable to assume that unobservable labor quality is similar between both genders within homogenous groups of highly motivated and successful workers, such as managers. On the other hand, if there are meaningful gender-related differences in the content of managerial jobs within our two hierarchy groups, then such differences will be captured by our ATT/'unexplained gap' measures.

There are available several algorithms for matching 'comparable' workers. Matching 'exactly' on the whole vector of observed covariates leads to the 'curse of dimensionality' as the number of data cells containing a given combination of $X$ increases with the number of covariates and the size of the available data within each cell dwindles. Fortunately, Rosenbaum and Rubin (1985) demonstrate that matching can be done on the conditional probability of 'participation' (in our context the conditional probability of being female) known as the propensity score, thus reducing the dimensionality problem considerably. Next, a 'similarity' distance must be chosen to guide the selection of controls (males) that are to be matched to a given treated individual (female). A related issue is the choice of an appropriate weighting function to assign 'importance' to each control observation based on its 'similarity' to the treated individual; see Heckman et al. (1999) and Smith and Todd (2000).

In this study we apply 'exact', kernel and Mahalanobis-metric matching with replacement. ${ }^{31}$ Exact matching, or cell matching, compares individuals with exactly the same set

\footnotetext{
${ }^{31}$ Matching is implemented in Stata 8 using the psmatch2 software suggested by Leuven and Sianesi (2003) and available at: http://ideas.repec.org/c/boc/bocode/s432001.html. 'Replacement' refers to the repeated use of the "untreated" (male) individuals in forming the matched comparison groups. Given that in our application the size of the treatment group is typically smaller than the control group size, matching with replacement is the only reasonable option.
} 
of values of the observed variables. Kernel matching is based on the estimated propensity scores and takes local averages of the untreated observations near each treated observation. ${ }^{32}$ Finally, Mahalanobis matching consists of matching on specific variables (a subset of $X$ that is assumed to be particularly important) in addition to the propensity score; it may decrease selection bias and may also serve as an additional protection against any impact due to inconsistent estimation of the propensity score. ${ }^{33}$

An assessment of the matching quality consists of checking whether the matching procedure is able to balance the distribution of the relevant variables across the control and treatment group. The basic idea of all approaches is to compare the situation before and after matching and check if there remain important differences after conditioning on the propensity score. To this effect we perform two-sample t-tests as suggested by Rosenbaum and Rubin (1985).

\section{Decomposition Results}

\subsection{Regression-Based Decompositions}

In this section we present the estimated conditional ('pure', 'unexplained') wage gaps based on the Oaxaca-Blinder procedure outlined in Section 5.1. Table 5 first lists the 'raw' average gender log-wage differentials and then the corresponding conditional gaps based on different regression specifications. The results are presented separately for top managers, lower managers and employees. The top panel of the Table uses Sample II while the bottom panel is based on Sample I.

Starting with the top panel, the unconditional log-wage gender gap in Sample II is -

\footnotetext{
${ }^{32}$ For exact matching, we use so-called 'pair' matching (one woman to all matched men); for propensity score matching, we use trimming to determine the common support, see Smith and Todd (2005).

${ }^{33}$ See Rubin (1980) and Rosenbaum and Rubin (1983) for further details.
} 
0.55 for top managers, -0.43 for lower managers and -0.22 for employees. Approximately a third of the raw gender wage gap for both top- and lower-level managers can be explained by the gender differences in age and education. This is in contrast to the situation with regular employees, where the demographic composition of the workforce is actually more favorable for women. Next, controlling only for firm characteristics but not for employee demographics suggests that the type of firm that is more likely to have female managers pays significantly lower wages. Firm ownership, size and industry explain up to 10 percentage points of the managerial gender wage gaps, but little of the regular-employee gap. While there are more women in the group of lower-level managers, they are sorted into less-paying types of firms in a fashion similar to that applying to top-level managers.

Looking at Sample I in the bottom panel, we see that the raw gap for both the top- and lower-level managers is smaller, by 5 and 7 percentage points, respectively, which appears to be driven by a year-specific fluctuation in these gaps in 2001- the year from which most of Sample I comes. ${ }^{34}$ This also affects the firm-type decomposition, which now explains little of the overall gender wage gaps for lower-level managers.

Finally, the overall conclusion of the presence of a sizeable 'unexplained' component of the managerial gender wage gap is confirmed in the bottom part of each panel of Table 5, where we present gaps controlling for both individual and firm characteristics. The top-managerial conditional log-wage gap is above -0.28 even in the richest specifications, where we introduce interaction terms between firm size and industry categories. The unexplained gaps are generally somewhat smaller for lower-level managers and decrease further when we focus on employees only. However, they remain above $20 \%$ even there. ${ }^{35}$

\footnotetext{
${ }^{34}$ Looking at raw gaps across years in our data suggests that the gap for lower-level managers is unusually low in 2001. About $80 \%$ of the wage records of firms covered by Sample I comes from 2001, while in the second sample the data are more evenly spread across years.

${ }^{35}$ In unreported specifications, we have controlled for firm characteristics fully, using a firm fixed effect.
} 
Comparing the results based on our two samples, we conclude that while sample composition does affect some of the quantitative results, the general patterns and their economic magnitude are highly similar. We also note that all of the estimated 'pure' gaps are precisely estimated. ${ }^{36}$ Our next question is to what extent these regression-based 'unexplained' wage gaps can be thought of as capturing the wage gap between truly comparable male and female managers. We therefore turn to the results based on matching methods.

\subsection{Matching-Based Decompositions}

To estimate the average treatment on the treated (ATT), we implement the kernel, ${ }^{37}$ Mahalanobis-metric, ${ }^{38}$ and exact matching procedures. But first, we estimate the propensity score - the probability that an individual with certain characteristics is female. Specifically, we run logit models controlling for the same set of observables used in the OLS wage

This led to a dramatic reduction in the gap. For example, the gap for top-level managers in the larger Sample II, estimated based on a specification with firm fixed effects and individual characteristics, shrinks to 0.13 . Unfortunately, the within-firm comparison for top managers comes from only 64 firms, which are mostly in manufacturing and almost all quite small.

${ }^{36}$ We have estimated an alternative set of 'pure' gaps using pooled-sample regressions where a femaledummy coefficient captured the 'unexplained' gap. For managers, the size of the 'pure' gap we thus obtained was almost identical to the results presented above based on Oaxaca-Blinder decompositions and all of the estimated female dummy coefficients, including those estimated for top managers, had a $p$ value below 0.01 .

${ }^{37}$ We experimented with different kernel functions and bandwidth parameters and found that these choices affected the ATT little. The reported results are based on the Epanechnikov kernel using an optimal bandwidth of 0.06 .

${ }^{38}$ The sub-set of $X$ used for matching on top of the propensity score consists of ownership, firm size, and industry indicators. 
regressions, entered in flexible forms as step functions and allowing for interaction terms. ${ }^{39}$

Table 6 shows the 'unexplained' wage gap from the regression-based decompositions together with the estimated ATT parameter from all three types of matching. Bootstrapped standard errors are reported below the average treatment effects, which are rather similar across the three types of matching, suggesting little sensitivity to the details of the matching technique. We note that the ATT estimates for top managers are smaller than the OLS-based conditional gaps, but remain large and are above zero with high levels of statistical significance. The Oaxaca-Blinder decomposition suggests that for top managers out of the raw log-wage gender gap of -0.55 , about -0.28 remain unexplained, while the ATT estimate ranges from -0.15 to -0.22 depending on the procedure. ${ }^{40}$

In contrast, the ATT for lower-level managers, at about -0.20 , is more similar to the OLS-based conditional gap. This is perhaps not surprising, given that the common support condition is less of a problem in the group of lower-level managers where women are more highly represented. The number of 'comparable' male and female wage records used in each decomposition is presented in the Table and shows that matching excludes from comparison only a few male and at most $9 \%$ of female lower-level managers. In stark contrast, the share of non-comparable top managers is high. Exact matching is the most strict procedure as it drops all observations that do not find a gender counterpart with the same set of all covariates (age and education group, industry, firm-size and owner class, and year); as a result only 79 females are matched with 251 males out of the original sample of 118 females and 1,572 males. Accounting for common support in terms of the

\footnotetext{
${ }^{39}$ Age enters as a step function with five-year intervals, education in four attainment-level dummies, and firm size as a step function in percentile steps. We also control for a set of year, industry and ownership dummies, and interact the firm size and industry terms.

${ }^{40}$ We also estimated specifications conditioning only on pre-market characteristics (age and education). For the top (lower-level) managers the exact-matching ATT estimate is -0.34 (-0.26).
} 
unidimensional propensity score is less restrictive, especially for men, but results in similar ATT estimates.

Matching indeed highlights the support problem in a way that regression does not. Let us consider for example the exact matching procedure. Starting with the raw wage gap for all top managers of -0.55 , we analyze only the small sub-sample of matched managers, where the raw gap happens to be -0.12 . This shows that a major part of the gap comes from the existence of non-comparable top male and female managers. Using matching averaging on the matched sub-sample (i.e. weighting the group-specific gender wage gaps with the distribution of the 'treated') then results in an unexplained gap of $-0.17 .{ }^{41}$

Finally, we note that both the kernel and the Mahalanobis matching procedures succeed in reducing the variability of observable characteristics across the two genders, which suggests high matching quality. ${ }^{42}$ We conclude that in the presence of low female representation among top managers, matching leads to lower 'unexplained' gaps compared to OLS decompositions, while there is little difference in the estimated conditional gaps across our diverse decomposition methods for the group of lower-level managers, where women are better represented.

\footnotetext{
${ }^{41}$ Naturally, applying the Oaxaca-Blinder decomposition on the exactly matched sub-sample does not allow one to explain any part of the gap there, given how balanced observables are across genders in this sub-sample.

${ }^{42}$ These diagnostic results are available upon request. We have evaluated pseudo- $\mathrm{R}^{2}$ statistics before and after matching separately for each procedure and each hierarchy level. In all cases there are no systematic differences in the distribution of covariates after matching and the pseudo- $\mathrm{R}^{2}$ is close to zero $(0.02$, down from 0.2 before matching). Similar conclusions come from F-tests on the joint significance of all regressors. There is no evidence of any disparity in the means once matching has been performed, thus confirming the validity of the balancing property and the matching procedure.
} 


\section{Relationships Across Hierarchy Levels}

Here, we explore some interesting correlations linking the three within-firm hierarchy levels that we have thus far analyzed separately. There are two potential interpretations of such within-firm linkages: Women in upper firm hierarchy levels could 'help' women enter lower-level positions and/or a high fraction of women among employees could lead to more females reaching the higher hierarchy levels. The first mechanism is featured in the economic theory of discrimination (Becker, 1985), where female managers are inclined to hire women into their firms because they may prefer to work with similar individuals. The alternative mechanism is natural to the extent that lower-level managers are recruited from employees and top-level managers were once lower-level managers. In the absence of information about the timing of the entry of female top managers, however, it is difficult to disentangle the likely two-way causality.

In a similar spirit, one can also ask whether the gender wage gaps of employees and lower-level managers are correlated with the fraction of females among top-level managers. Such analysis has been recently performed by Bell (2005), who explores the correlation of the presence of a female CEO with the relative standing of female employees in U.S. companies. She concludes that women are relatively better off in women-led firms in terms of pay and that having more women in a firm is positively associated with the chances of a woman reaching the top of the firm.

Our initial analysis of this issue links the share of women across adjacent hierarchy levels within firms. Specifically, we regress the firm-specific share of women among employees on the firm's share of women among low-level managers, controlling for a full set of firm-type observables used in the gender gap decompositions presented above. We then repeat this analysis for all combinations of adjacent hierarchy levels. In all specifications we find similar statistically significant coefficients of about 0.3 to 0.4 . Next, we ask similar 
descriptive questions for the firm- and hierarchy-specific gender wage gap. For instance, we regress the gap among employees on the share of women among lower-level managers and then use all other combinations. ${ }^{43}$ Again, we find a highly similar set of significant conditional correlations with a coefficient of about -0.1. In sum, there is a statistically strong positive link at the firm level between the fraction of women at various hierarchy levels and a negative link between the gender wage gap at a given hierarchy level and the presence of women at other levels. These results are in accord with those Bell (2005) reports for the U.S.; they are consistent with Czech firms differing in a systematic way in how friendly they are to women. ${ }^{44}$

Table 7 then presents specifications where we simultaneously condition on the fraction of women in the other two firm hierarchy levels. Particularly interesting is the middle panel of the Table, in which we ask whether there are more female lower-level managers in firms that have, ceteris paribus, a higher share of female employees or a higher fraction of female top-level managers. We find that a high fraction of women at a lower hierarchy level predicts the representation of women at a given level better than the share of women at a higher hierarchy level; the regression estimates thus support the notion that lower-level managers are promoted from among the employees. In most specifications, however, the data do not allow us to distinguish between the effects of female representation at several hierarchy levels.

\footnotetext{
${ }^{43}$ We measure the firm-specific wage gap using the female dummy from a series of firm-specific pooled wage regressions. In terms of Equation 1 we capture the 'unexplained' gap by the female dummy coefficient.

${ }^{44}$ These results also suggest that the firm-specific gender wage gap among top managers, which we cannot effectively measure, is likely to be related to that among lower-level managers. Using this premise, we can ask whether firms in our data not reporting the wages of top managers (see Section 3) have unusual gender wage gaps for lower level managers. We did not find any connection between these two firm-level variables; these results are available upon request.
} 


\section{Comparison to U.S. Findings}

While we have estimated the gender wage gap among Czech managers using several techniques, it is not clear how large the Czech gap is in an international perspective. Bertrand and Hallock (2001) study the gender pay differential of the five highest-paid executives in a sample of large publicly traded firms in the U.S. In order to compare the Czech managerial gender gap to the U.S. one, we therefore select and separately study the five highest-paid managerial employees from each firm in our ISAE sample. The U.S. and Czech firm samples are, however, not comparable in terms of average firm size as the ExecuComp data covers much larger firms from the S\&P 1500. Bertrand and Hallock (2001) also report the U.S. managerial wage gap from the Current Population Survey (CPS), which includes not only top-level managers but all managerial occupations; ${ }^{45}$ the managerial coverage of the CPS and ISAE data is thus more comparable.

The share of females among the five highest-paid managers in each of the Czech firms in our sample is $9 \%$, which is similar to the $7 \%$ of women among Czech CEOs reported by Eriksson (2005), and which compares favorably to the 2.5-6\% in the ExecuComp U.S. data. The ratio of female to male pay among the five highest-paid Czech managers is $74 \%$, which is comparable to the $73 \%$ ratio for executive salary measured in the U.S. by Bertrand and Hallock (2001). ${ }^{46}$ Comparing the combined group of top- and lower-level Czech managers to the CPS managerial occupations covered by Bertrand and Hallock (2001), the Czech raw wage gap appears about a third smaller in comparison to the U.S. gap.

How does the structure of the Czech wage gap for the highest-paid managers compare

\footnotetext{
${ }^{45}$ Specifically, they report on full-time workers in an occupation category between 3 and 22 in the 1980 Census of Population Occupational Classification.

${ }^{46}$ However, the U.S. gap based not only on sallary, but on total compensation, is larger at $67 \%$.
} 
to that estimated in the U.S.? To answer this question, we have estimated a series of pooled regressions with a female dummy on the sub-sample of the five highest-paid Czech managers and compared our results to those of Bertrand and Hallock (2001) based on total compensation. ${ }^{47}$ The results are presented in Table 8. The mean Czech gender log-wage differential is $35 \%$. About a fifth of it, or 8 percentage points, can be accounted for by the lower participation of women in large firms. Indeed, $74 \%$ of the five highest-paid female managers appear in the smallest firms. In the U.S., however, the effect of sorting in large firms is stronger as a third of the whole gap is explained by the lack of women in the higher paying large firms. The different representation of women across industries does not affect the Czech gap in column (3), similarly to the U.S. case. Finally, in column (4) we additionally control for occupational structure among the highest paid executives. Specifically, we introduce a dummy variable differentiating between directors and chief executive officers on the one hand and financial, sales, personnel and R\&D managers on the other hand. ${ }^{48}$ The scarcity of female directors and chief executive officers explains a substantial part of the gender compensation differential. The combined effects of occupational, industrial and firm-size segregation reduced the Czech 'unexplained' gap measured by the female dummy estimate to -0.20 . This is a larger conditional gap compared to the U.S. analysis presented in column (5).

Overall, we find the representation of women at the top of U.S. and Czech firms very similar. While the Czech managerial raw gaps are somewhat lower, the power of our Czech data to explain these gaps is lower compared to the U.S. case; however, there are

\footnotetext{
${ }^{47}$ This strategy corresponds to the Oaxaca-Blinder decomposition we used in the main body of this paper (Equation 1) to the extent that the pooled regression coefficients are close to the male parameters and to the extent that the introduction of the female dummy to the pooled regression does not affect its slope parameters.

${ }^{48}$ See Section 3 , note 12 , for details on the data.
} 
similarities in the structure of wage gap across the two countries.

\section{Conclusion}

This paper presents the first available evidence on the gender structure of managerial employment and wages outside of the most developed economies - in a post-communist country at the time of its accession to the EU. We study managerial wage gaps using an intuitively appealing matching approach, which recognizes the lack of comparable female managers for many male managers, particularly those of the largest companies. Unlike most of the existing work on managers, our analysis covers not only top executives, but also mid-level managers and employees, thereby allowing us to link the relative position of women across firm hierarchy levels.

We find that at $7 \%$ women are severely under-represented in top managerial positions, and that there is a clear gender divide between lower- and top-level managerial ranks. Given that the raw average pay gap between men and women increases with firm hierarchy level, as the fraction of women dwindles, descriptive statistics suggest an increasingly female-unfriendly environment as workers progress towards higher hierarchy levels.

However, our wage-gap decomposition analysis suggests that the size of the wage gap that cannot be linked to observable differences between men and women is quite similar across hierarchies. To the extent that this conditional wage gap can be interpreted as an upper bound on potential on-the-job discriminatory wage setting, this suggests that women are treated similarly at the top and bottom of firms, once they are there. A large part of the average wage difference across genders among top managers is then related to the different types of firms that women and men typically head. This conclusion is reached based on the matching analysis, while the traditional Oaxaca-Blinder decomposition technique would maintain the existence of larger 'unexplained' gender wage gaps among top managers - a 
group of workers for which the differences in 'common support' of men and women are the strongest. These results are robust to applying several alternative matching techniques.

Our main finding is therefore twofold: After comparing the wage rates of women and men who are comparable in terms of basic demographic characteristics, employer type and within-firm hierarchical position, there remains a gender wage gap of about 20 percent; this figure is quite comparable to similar estimates from the U.S. The key reason for why the relative wage position of Czech female top managers is worse compared to lower-ranking female employees is that they tend not to be present at the top of the highest-paying companies. The policy implication of these findings is that equality-enhancing policies aimed at the highly visible group of executives are more likely to be effective in equalizing wages of male and female top managers if they focus on promotion policies in the most prestigious companies. Finally, similar to recent work on the U.S., our evidence suggests that the gender wage gap at a given within-firm hierarchy level is smaller in firms that feature a higher presence of women at other hierarchy levels. 


\section{Bibliography}

Albrecht, J., Bjorklund, A., and S. Vroman (2003) "Is There a Glass Ceiling in Sweden?" Journal of Labor Economics, 21 (1), 145-177.

Babcock, L. and S. Laschever (2003) Women Don't Ask: Negotiations and the Gender Divide, Princeton University Press, Princeton, New Jersey.

Baker, G., M. Jensen and K. J. Murphy (1988) "Compensation and Incentives: Practice vs. Theory," Journal of Finance, 43(3), 593-616.

Becker, G. (1985) "Human Capital, Effort, and the Sexual Division of Labor," Journal of Labor Economics, 3, 33-58.

Bell, Linda A. (2005) "Women-Led Firms and the Gender Gap in Top Executive Jobs", IZA Discussion Paper No. 1689.

Bertrand, M. and K. Hallock (2001) "The Gender Gap in Top Corporate Jobs," Industrial and Labor Relations Review, 55, 1-21.

Black, D., A. Haviland, S. Sanders and L. Taylor (2004) "Gender Wage Disparities Among the Highly Educated," mimeo, Center for Policy Research, Syracuse University.

Blau, F. and M. Ferber (1987) "Discrimination: Empirical Evidence from the United States," American Economics Review, 77(2), 316-320.

Bonin, J., D. Jones and L. Putterman (1993) "Theoretical and Empirical Studies of Producer Cooperatives: Will Ever the Twain Meet?," Journal of Economic Literature, 31, 1290-1320.

Costa, D. (2000) "From Miss Town to Board Room: The Rise of Women's Paid Labor," Journal of Economic Perspectives, 14, 101-122.

Denis D. and J. McConnel (2003) "International Corporate Governance," Working Paper No 5, SSRN.

Eriksson T. (2005) "Managerial Pay and Executive Turnover in the Czech and Slovak Republics," forthcoming in Economics of Transition 13 (4), 659-677. 
Gneezy, U., Niederle, M., and A. Rustichini (2003) "Performance in Competitive Environments: Gender Differences," Quarterly Journal of Economics, 118 (3), 1049 - 1074.

Gregg, P. and S. Machin (1993) "Is the Glass Ceiling Cracking? Gender Compensation Differentials and Access to Promotion among UK Executives," University College London, Discussion Paper 94-05, July.

Heckman, J.J., H. Ichimura and P. Todd (1997) "Matching as an Econometric Evaluation Estimator: Evidence from Evaluating a Job Training Program" Review of Economic Studies (64), 605-654.

Heckman, J.J., H. Ichimura and P. Todd (1998) "Matching as an Econometric Evaluation Estimator," Review of Economic Studies (65), 261-294.

Heckman, J.J., R. LaLonde, and J. Smith (1999) "The Economics and Econometrics of Active Labor Market Programs," in Handbook of Labor Economics, III, ed. by O. Ashenfelter and D. Card, 1865-2097, Elsevier.

Heckman, Lochner, and Todd (2003) "Fifty Years of Mincer Earnings Regressions," Working Paper 9732, National Bureau of Economic Research.

Holmstrom, B. (1979) "Moral Hazard and Observability," The Bell Journal of Economics, 10, 74-91.

ILO (2003) Yearbook of Labour Statistics, ILO Geneva.

ILO (2004) Breaking Through the Glass Ceiling: Women in Management, ILO Geneva.

Jolliffe, D. and N.F. Campos (2005) "Does Market Liberalization Reduce Gender Discrimination? Econometric Evidence from Hungary, 1986-1998," Labour Economics, 12 (1), 1-22.

Jurajda S. (2005) "Gender Segregation and Wage Gap: An East-West Comparison," Journal of the European Economic Association, Papers and Proceedings, 3 (2-3), 598-607.

Munich, D., Svejnar, J., and K. Terrell (2005) "Is Women's Human Capital Valued More by Markets than by Planners?" Journal of Comparative Economics, 33(2), 278-299. 
Murphy, K.J. (1999) "Executive Compensation" Handbook of Labor Economics, Vol. 3B, Elsevier Science, North-Holland, 2485-2563.

Nopo, H. (2004) "Matching as a Tool to Decompose Wage Gaps," IZA Discussion Paper No. 981.

Oaxaca, R. (1973) "Male-Female Differentials in Urban Labor Markets," International Economic Review, 14, 693-709.

Oaxaca, R.L. and M.R. Ransom (1994) "Discrimination and Wage Decomposition," Journal of Econometrics, 61, 5-22.

Ogloblin, C.G. (1999) "The Gender Earnings Differential in the Russian Transition Economy," Industrial and Labor Relations Review, 52(4), 602-627.

Rosenbaum, P. and D. Rubin (1983) "The Central Role of the Propensity Score in Observational Studies for Causal Effects," Biometrica, 70, 41-55.

Rosenbaum, P. and D. Rubin (1985) "Constructing a Control Group Using Multivariate Matched Sampling Methods that Incorporate the Propensity Score," The American Statistician, 39 (1), 33-38.

Rubin, D.B. (1980) "Bias Reduction Using Mahalanobis-Metric Matching," Biometrics, 36, 293298.

Smith J. and P. Todd (2005) "Does Matching Overcome LaLonde's Critique of Nonexperimental Estimators?," Journal of Econometrics, 125(1-2), 305-353.

Wood, R.G., M.E. Corcoran, and P.N. Courant (1993) "Pay Differences among the Highly Paid: The Male-Female Earnings Gap in Lawyers' Salaries," Journal of Labor Economics, 11, 3, $417-441$. 
Table 2: ISAE Sample Size Across Years

\begin{tabular}{lcccccc}
\hline & 2000 & 2001 & 2002 & 2003 & 2004 & Total \\
\hline Pooled Sample & & & & & & \\
Firms & 546 & 733 & 646 & 643 & 729 & 3,297 \\
Non-reporting firms & 159 & 259 & 189 & 199 & 212 & 1,018 \\
Top-level managers & 718 & 854 & 821 & 862 & 1,032 & 4287 \\
\% Females & 6.13 & 6.21 & 6.58 & 5.45 & 5.14 & 5.85 \\
Lower-level managers & 21,196 & 24,483 & 27,879 & 29,125 & 36,549 & 139,232 \\
\% Females & 25.34 & 25.61 & 30.92 & 28.64 & 33.51 & 29.34 \\
\hline Sample I & & & & & & \\
Firms & 24 & 474 & 51 & 23 & 20 & 592 \\
Top-level managers & 43 & 854 & 65 & 51 & 62 & 1,075 \\
\% Females & 7 & 6 & 15 & 2 & 11 & 7 \\
Lower-level managers & 664 & 11,370 & 2,004 & 1,906 & 1,494 & 17,438 \\
\% Females & 31 & 37 & 39 & 24 & 14 & 33 \\
\hline Sample II & 5,959 & 4,795 & 4,300 & 13,866 & 10,134 & 36,054 \\
Firms & 18 & 39 & 25 & 21 & 49 & 32 \\
Top-level managers & 167 & 318 & 249 & 620 & 338 & 1,692 \\
\% Females & 59 & 119 & 125 & 344 & 136 & 783 \\
Lower-level managers & & 9 & 9 & 5 & 9 & 7 \\
\% Females & & & & & \\
\hline
\end{tabular}


Table 3: Demographic Gender Employment and Wage Patterns

\begin{tabular}{|c|c|c|c|c|c|c|c|c|c|}
\hline & \multicolumn{6}{|c|}{ Managers } & \multicolumn{3}{|c|}{ Employees } \\
\hline & \multicolumn{3}{|c|}{ Top-Level } & \multicolumn{3}{|c|}{ Lower-Level } & \multirow{3}{*}{$\begin{array}{l}\text { Fem. } \\
\%\end{array}$} & \multirow{3}{*}{$\begin{array}{l}\text { Rel. } \\
\text { Pay }\end{array}$} & \multirow{3}{*}{$\begin{array}{l}\text { Pay } \\
\text { Gap }\end{array}$} \\
\hline & Fem. & Rel. & Pay & Fem. & Rel. & Pay & & & \\
\hline & $\%$ & Pay $^{a}$ & $\mathrm{Gap}^{b}$ & $\%$ & Pay & Gap & & & \\
\hline Overall & 7 & 1 & -0.41 & 32 & 1 & -0.38 & 40 & 1 & -0.22 \\
\hline \multicolumn{10}{|l|}{ Age } \\
\hline$\leq 39$ & 8.7 & 0.93 & -0.51 & $34.8^{*}$ & 0.98 & -0.44 & $38.8^{*}$ & 0.99 & -0.19 \\
\hline $40-49$ & 8.1 & 1.01 & -0.33 & $34.1^{*}$ & 1.02 & -0.36 & $45.4^{*}$ & 1.01 & -0.21 \\
\hline$\geq 50$ & 5.2 & 1.02 & -0.43 & $26.6^{*}$ & 0.99 & -0.33 & $36.9^{*}$ & 1.01 & -0.20 \\
\hline \multicolumn{10}{|l|}{ Education } \\
\hline Lower & $12.6^{*}$ & $0.63^{*}$ & -0.43 & $45.8^{*}$ & 0.70 & $-0.32^{*}$ & 0.4 & $0.93^{*}$ & -0.20 \\
\hline University & 5.6 & 1.08 & -0.33 & $17.5^{*}$ & 1.33 & $-0.18^{*}$ & $0.3^{*}$ & $1.71^{*}$ & -0.15 \\
\hline
\end{tabular}


Table 4: Firm-Type Gender Employment and Wage Patterns

Managers

Employees

Top-Level Lower-Level

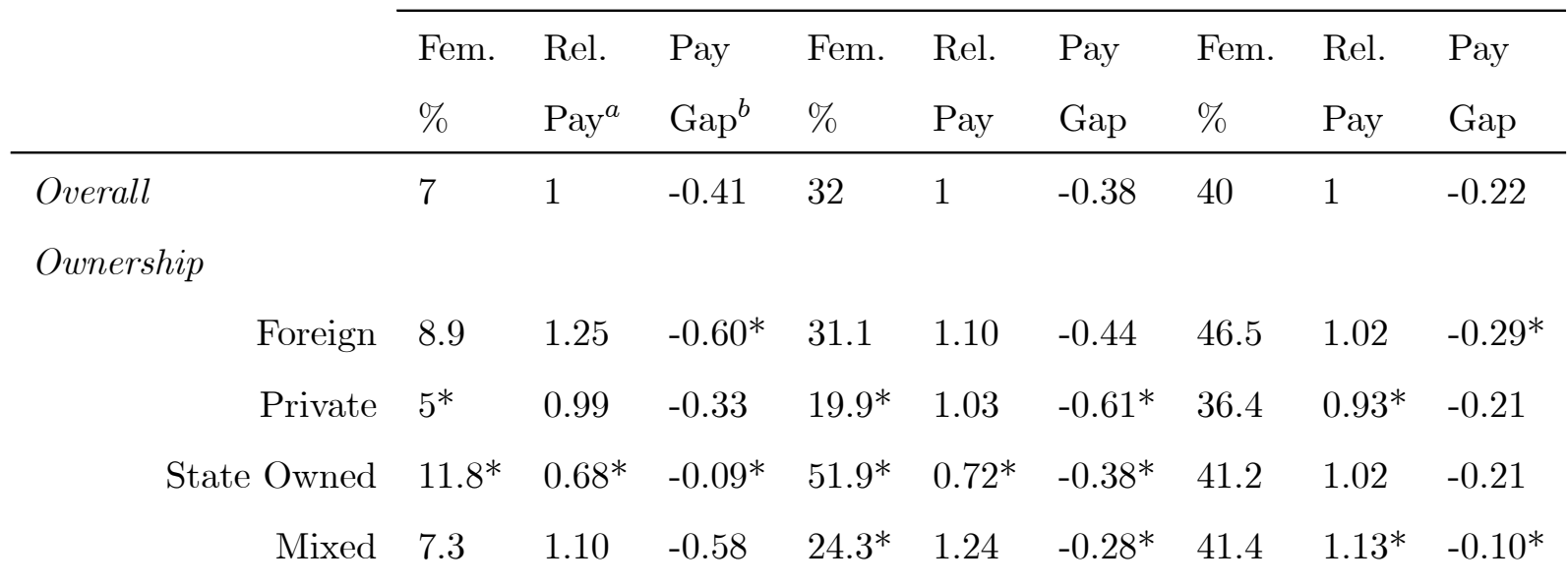

Firm size

$\begin{array}{rlllllllll}250-625 & 6.6 & 0.89^{*} & -0.24 & 22.3^{*} & 1.01 & -0.20^{*} & 37 & 0.91^{*} & -0.17^{*} \\ 626-1310 & 4^{*} & 1.23^{*} & -0.35 & 18.3^{*} & 1.18^{*} & -0.25^{*} & 37.8 & 1.04 & -0.15 \\ 1311-3500 & 6.9 & 1.22 & -0.57 & 23.3^{*} & 1.08^{*} & -0.34 & 39.1 & 0.98 & -0.22 \\ \text { over } 3500 & 11.1^{*} & 0.76 & -0.51 & 42.8^{*} & 0.92 & -0.44 & 41.7 & 1.06 & -0.21\end{array}$

Industry

\begin{tabular}{|c|c|c|c|c|c|c|c|c|c|}
\hline Agriculture & 2 & $0.52^{*}$ & $-0.22^{*}$ & $11.2^{*}$ & $0.66^{*}$ & $-0.20^{*}$ & $20.8^{*}$ & 0.99 & -0.22 \\
\hline Manufacturing $^{c}$ & 5.9 & 1 & -0.47 & $17^{*}$ & 1.05 & $-0.24^{*}$ & $35.8^{*}$ & 0.97 & $-0.23^{*}$ \\
\hline Utilities & 6.7 & 0.99 & -0.25 & $14.9^{*}$ & 1.07 & $-0.26^{*}$ & $14.9^{*}$ & 1.01 & $-0.05^{*}$ \\
\hline Construction & 0.0 & 1.27 & - & $14.5^{*}$ & 1.17 & -0.29 & $59.3^{*}$ & $0.74^{*}$ & -0.3 \\
\hline Retail & $12.7^{*}$ & 0.85 & $-0.60^{*}$ & $49.4^{*}$ & $0.65^{*}$ & -0.40 & 42.8 & 1.04 & -0.19 \\
\hline Transport & $12.5^{*}$ & 0.90 & -0.24 & $50.8^{*}$ & 0.80 & -0.43 & 40 & $0.82^{*}$ & -0.18 \\
\hline Banking \& Insurance & 12 & $1.90^{*}$ & -0.43 & $42.7^{*}$ & $1.73^{*}$ & -0.47 & $55.7^{*}$ & 0.91 & -0.27 \\
\hline Services & 4.5 & 0.95 & -0.46 & 32 & 1.01 & -0.27 & $74.6^{*}$ & 1.4 & $-0.32^{*}$ \\
\hline
\end{tabular}

Notes: ${ }^{a}$ Ratio of the average pay by firm-type category to average pay in each hierarchy level.

${ }^{b}$ Ratio of average pay of women to average pay of men by firm type minus one. ${ }^{c}$ Manufacturing includes mining and metallurgy. ${ }^{*}$ denotes groups where the fraction of women is different from the overall fraction in the hierarchy level with a p value below 0.01 , similarly for the gender pay gap and the relative pay. 
Table 5: OLS Conditional ('Unexplained') Log-Wage Gender Gaps

\begin{tabular}{|c|c|c|c|}
\hline & \multicolumn{2}{|c|}{ Managers } & \multirow[t]{2}{*}{ Employees } \\
\hline & Top-Level & Lower-Level & \\
\hline \multicolumn{4}{|c|}{ Sample II } \\
\hline Raw Gaps & -0.55 & -0.43 & -0.22 \\
\hline \multicolumn{4}{|l|}{ Gaps Conditional on } \\
\hline \multicolumn{4}{|c|}{ Individual Characteristics } \\
\hline Age and Education & -0.37 & -0.27 & -0.25 \\
\hline \multicolumn{4}{|c|}{ Firm Characteristics } \\
\hline Ownership, Size, Industry & -0.47 & -0.37 & -0.20 \\
\hline Ownership, Size and Industry Interacted & -0.45 & -0.35 & -0.19 \\
\hline \multicolumn{4}{|c|}{ Firm and Individual Characteristics } \\
\hline Size and Industry Interacted & -0.29 & -0.24 & -0.21 \\
\hline No Interactions & -0.30 & -0.25 & -0.22 \\
\hline \multicolumn{4}{|c|}{ Sample I } \\
\hline Raw Gap & -0.50 & -0.36 & -0.23 \\
\hline \multicolumn{4}{|l|}{ Gaps Conditional on } \\
\hline \multicolumn{4}{|c|}{ Individual Characteristics } \\
\hline Age and Education & -0.31 & -0.21 & -0.25 \\
\hline \multicolumn{4}{|c|}{ Firm Characteristics } \\
\hline Ownership, Size, Industry & -0.49 & -0.39 & -0.19 \\
\hline Ownership, Size and Industry Interacted & -0.42 & -0.35 & -0.20 \\
\hline \multicolumn{4}{|c|}{ Firm and Individual Characteristics } \\
\hline Size and Industry Interacted & -0.28 & -0.27 & -0.21 \\
\hline No Interactions & -0.30 & -0.29 & -0.22 \\
\hline
\end{tabular}


Table 6: Matching Results: Top and Lower-Level Managers

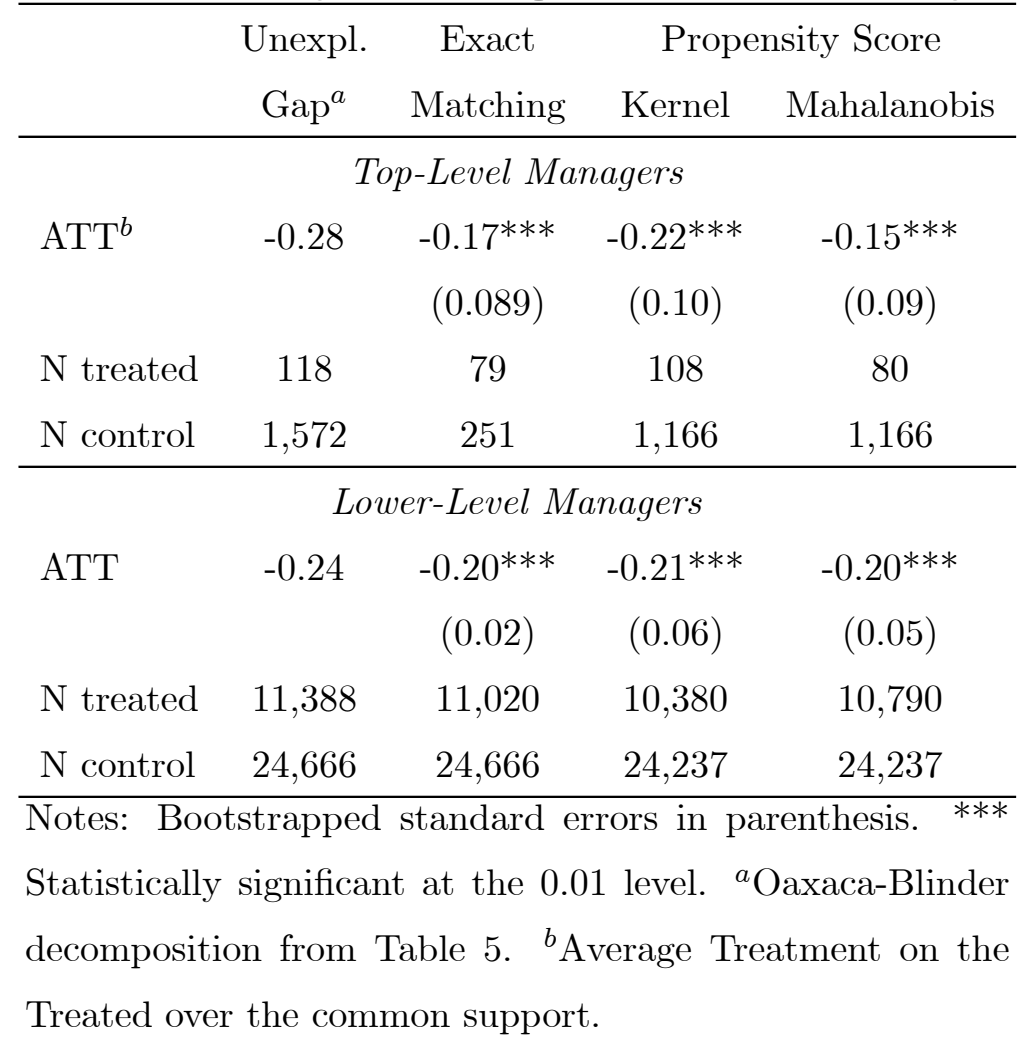

Table 7: Gender Relationships Across Firm Hierarchy Levels

\begin{tabular}{lccccc}
\hline & \multicolumn{2}{c}{ Employees } & \multicolumn{2}{c}{ Lower-Level } & Top-Level \\
\cline { 2 - 6 } Explanatory variables & \% Fem. & Wage Gap & \% Fem. & Wage Gap & \% Fem. \\
\hline \% Fem. Employees & & & $0.71^{*}$ & -0.58 & 0.16 \\
& & & $(0.37)$ & $(0.41)$ & $(0.28)$ \\
\% Fem. Lower-Level Managers & $0.31^{*}$ & -0.25 & & & 0.52 \\
& $(0.12)$ & $(0.16)$ & & & $(0.36)$ \\
\% Fem. Top-Level Managers & 0.18 & 0.03 & 0.13 & 0.20 & \\
& $(0.15)$ & $(0.09)$ & $(0.22)$ & $(0.19)$ & \\
\hline
\end{tabular}

Notes: Each column represents a separate specification controlling for year, industry, firmsize and ownership indicators with either the fraction of women or the gender wage gap on the left-hand side. Wage-gap regressions are weighted with the inverse of the standard errors of the estimated firm-specific gaps. ${ }^{* * *}$ Denotes statistical significance at the 0.01 level. 
Table 8: Gender Wage Gap Among the Five Highest-Paid Managers

\begin{tabular}{lccccc}
\hline Country & CZ & CZ & CZ & CZ & US \\
& $(1)$ & $(2)$ & $(3)$ & $(4)$ & $(5)$ \\
\hline Female & $-0.35^{* * *}$ & $-0.27^{* * *}$ & $-0.26^{* * *}$ & $-0.20^{* * *}$ & $-0.11^{* * *}$ \\
& $(0.05)$ & $(0.04)$ & $(0.04)$ & $(0.04)$ & $(0.03)$ \\
Firm size & No & Yes & Yes & Yes & Yes \\
Industry & No & No & Yes & Yes & Yes \\
Occupation & No & No & No & Yes & Yes \\
N & 3,853 & 3,846 & 3,846 & 3,726 & 42,677 \\
\hline Notes: All Czech regressions control for year dummies. The U.S. \\
results are taken from Bertrand and Hallock (2001). Residuals \\
are clustered at firm level. *** Statistically significant at the 0.01 \\
level.
\end{tabular}


Individual researchers, as well as the on-line and printed versions of the CERGE-EI Working Papers (including their dissemination) were supported from the following institutional grants:

- Center of Advanced Political Economy Research [Centrum pro pokročilá politicko-ekonomická studia], No. LC542, (2005-2009),

- Economic Aspects of EU and EMU Entry [Ekonomické aspekty vstupu do Evropské unie a Evropské měnové unie], No. AVOZ70850503, (2005-2010);

- Economic Impact of European Integration on the Czech Republic [Ekonomické dopady evropské integrace na ČR], No. MSM0021620846, (2005-2011);

Specific research support and/or other grants the researchers/publications benefited from are acknowledged at the beginning of the Paper.

(c) Štěpán Jurajda, Teodora Paligorova, 2006

All rights reserved. No part of this publication may be reproduced, stored in a retrieval system or transmitted in any form or by any means, electronic, mechanical or photocopying, recording, or otherwise without the prior permission of the publisher.

Published by

Charles University in Prague, Center for Economic Research and Graduate Education (CERGE) and

Economics Institute (EI), Academy of Sciences of the Czech Republic

CERGE-El, Politických vězňů 7, 11121 Prague 1, tel.: +420 224005 153, Czech Republic.

Printed by CERGE-EI, Prague

Subscription: CERGE-EI homepage: http://www.cerge-ei.cz

Editors: Directors of CERGE and EI

Managing editors: Deputy Directors for Research of CERGE and EI

ISSN 1211-3298

ISBN 80-7343-091-6 (Univerzita Karlova. Centrum pro ekonomický výzkum a doktorské studium) ISBN 80-7344-080-6 (Akademie věd České republiky. Národohospodářský ústav) 
CERGE-EI

P.O.BOX 882

Politických vězňů 7

11121 Praha 1

Czech Republic http://www.cerge-ei.cz 